\title{
Isolation and identification of Mycobacterium bovis in bovines with positive reaction to the tuberculin test in the state of Paraíba, northeast Brazil
}

\author{
Isolamento e identificação de Mycobacterium bovis em bovinos positivos \\ no teste de tuberculinização no estado da Paraíba, nordeste do Brasil
}

\author{
Joelson Marcolino Ramos', Marcos Bryan Heinemann², José Soares Ferreira Neto², Antonio Francisco \\ de Souza Filho² ${ }^{\text {DD }}$, Nicolás Céspedes Cárdenas², Antônio Flávio Medeiros Dantas', Clebert José Alves', \\ Sérgio Santos de Azevedo ${ }^{*}$
}

\begin{abstract}
In areas where human tuberculosis and bovine tuberculosis coexist, differentiation between $M$. bovis and $M$. tuberculosis is important for monitoring the spread of $M$. bovis among cattle and from cattle to humans. The objective of this study was to isolate and identify $M$. bovis in bovines with positive diagnosis identified on tuberculin test in the State of Paraíba, Northeastern Brazil. Thirty-two bovines that tested positive in the comparative tuberculin test were used, from which samples of any organ with lesions suggestive of tuberculosis were collected, as well as lymph nodes, when no gross lesions were observed. Samples were submitted to histopathological exam, mycobacterial culture, Ziehl-Neelsen staining and molecular diagnosis. Twenty-one (65.6\%) animals presented lesions suggestive of tuberculosis. As to body region $77.7 \%$ of lesions were found in the thoracic cavity, $12.4 \%$ in the head and $9.9 \%$ in the abdominal cavity. Among 55 samples submitted to mycobacterial culture, mycobacteria were isolated in $31(56.4 \%)$, being $13(41.9 \%)$ identified as M. bovis and 18 (58.1\%) as Mycobacterium spp. Conclusion is that isolation and identification of $M$. bovis and Mycobacterium spp. in cattle suggests that humans are exposed to the risk of infection. This reinforces the need for intensification and optimization of prevention and control measures foreseen in the Brazilian National Program for the Control and Eradication of Bovine Brucellosis and Tuberculosis. Mycobacteria isolation and identification surveys are, therefore, encouraged in other Northeastern states.
\end{abstract}

KEYWORDS: bovine; immunodiagnosis; isolation and molecular identification; mycobacteria.
RESUMO: Em áreas onde a tuberculose humana e a tuberculose bovina coexistem, a diferenciação entre $M$. bovis e $M$. tuberculosis é importante para monitorar a disseminação de $M$. bovis entre bovinos e destes para os seres humanos. Objetivou-se neste estudo isolar e identificar $M$. bovis em bovinos com diagnóstico positivo pelo teste de tuberculinização no estado da Paraíba, nordeste do Brasil. Foram submetidos 32 bovinos positivos ao teste de tuberculinização comparativa, dos quais foram colhidas amostras de qualquer órgão com lesôes sugestivas de tuberculose, e, nos casos em que não foram observadas lesôes sugestivas, foram colhidas amostras de linfonodos. As amostras foram submetidas a exame histopatológico, cultivo micobacteriológico, coloração de Ziehl-Neelsen e diagnóstico molecular. Apresentaram lesóes sugestivas de tuberculose 21 animais $(65,6 \%)$. Com relação à distribuiçáo das lesóes de acordo com a região corporal, $77,7 \%$ localizavam-se na cavidade torácica, $12,4 \%$ na cabeça e $9,9 \%$ na cavidade abdominal. De 55 amostras submetidas ao cultivo de micobactérias, em 31 $(56,4 \%)$ foram isoladas micobactérias, sendo que em 13 (41,9\%) foi identificado $M$. bovis, e nas 18 restantes $(58,1 \%)$ foi identificado Mycobacterium spp. Conclui-se que o isolamento e a identificação de $M$. bovis e Mycobacterium spp. em bovinos indicam que os seres humanos estão expostos ao risco de infecção. Isso reforça a necessidade de intensificação e otimização de medidas de prevenção e controle previstas no Programa Nacional de Controle e Erradicação da Brucelose e Tuberculose Bovina. Sugere-se a realização de estudos de isolamento e identificação de micobactérias em outros estados do Nordeste.

PALAVRAS-CHAVE: bovino; imunodiagnóstico; isolamento e identificação molecular; micobactérias.

'Universidade Federal de Campina Grande - Patos (PB), Brazil

${ }^{2}$ Universidade de São Paulo - São Paulo (SP), Brazil

*Corresponding author: sergio@vps.fmvz.usp.br

Received on: $11 / 27 / 2016$. Accepted on: 04/19/2018

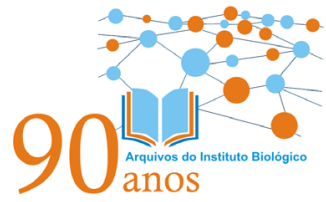




\section{INTRODUCTION}

Bovine tuberculosis is a chronic zoonotic disease caused by Mycobacterium bovis, which belongs to the Mycobacterium tuberculosis complex (BRASIL, 2006). Its diagnosis can be made by direct and indirect methods. Direct methods involve detection and identification of the etiologic agent in biological material, and the combination of isolation in culture medium and molecular identification with genotyping has contributed to a better understanding of the epidemiology of $M$. bovis infections, which provides greater efficiency to control programs (CAZOLA et al., 2015).

Although tuberculosis in humans is mostly caused by M. tuberculosis, $3.1 \%$ of the cases of human tuberculosis across the world are caused by $M$. bovis (EL SAYED et al., 2015). However, in general, infection in humans is not confirmed by agent isolation and identification, making it impossible to identify the possible source of infection. In addition, human diseases caused by $M$. tuberculosis and $M$. bovis are indistinguishable by clinical, radiological and pathological methods (ROCHA et al., 2011). The distinction of the various members of the M. tuberculosis complex is essential for the epidemiological investigation of bovine cases (OCEPEK et al., 2005). Therefore, the differentiation between M. bovis and $M$. tuberculosis is important for the identification of possible source of infection and routes of transmission, which are fundamental for an effective control and eradication of the infirmity (ZANINI et al., 2001; RODRIGUEZ et al., 2004). Transmission of $M$. bovis to humans occurs through ingestion of meat, raw milk and dairy products from infected cattle or contact with secretions of fistulized abscesses and aerosols.

Official data indicate 1,015 cases of human tuberculosis in 2014 in the State of Paraíba (BRASIL, 2015). The differentiation between $M$. bovis and M. tuberculosis is important so as to monitor the spread of $M$. bovis among cattle and transmission to humans in areas where both types of tuberculosis coexist. Thus, the objective of this study was to isolate and identify M. bovis in cattle tested positive for tuberculin in the State of Paraíba, northeast Brazil.

\section{MATERIAL AND METHODS}

Thirty-two bovines, aged two to ten years old, with positive reaction in comparative tuberculin test, were assessed. They were from eight rural properties with mixed livestock characteristics and no history of tuberculosis, located in the municipalities of Cacimba de Areia, Patos and São Mamede, in mesoregion of Sertão, state of Paraíba, northeast Brazil, from March to November 2014. The properties were named A (Coordinates: 070. $41.7^{\prime \prime}$ 'S 37 $\left.07^{\prime} 16.7^{\prime \prime} \mathrm{W}\right)$, B

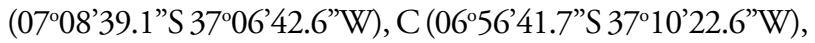

D (06058'37.3”S 37016’38.7”W), E (06'58'36.0”S $\left.37^{\circ} 17^{\prime} 21.9^{\prime \prime} \mathrm{W}\right), \mathrm{F}\left(07^{\circ} 00^{\prime} 24.3^{\prime \prime S} 37^{\circ} 16^{\prime} 15.6^{\prime \prime} \mathrm{W}\right)$, G $\left(07^{\circ} 01^{\prime} 46.5^{\prime \prime} \mathrm{S} 37^{\circ} 16^{\prime} 26.4^{\prime \prime} \mathrm{W}\right)$ and $\mathrm{H}\left(06^{\circ} 57^{\prime} 53.5^{\prime \prime} \mathrm{S}\right.$ $\left.37^{\circ} 20^{\prime} 32.2^{\prime \prime} \mathrm{W}\right)$. The comparative tuberculin test was carried out as per the standards established in the technical manual of the Brazilian National Program for the Control and Eradication of Brucellosis and Tuberculosis (PNCEBT, acronym in Portuguese) (BRASIL, 2006), and the euthanasia and necropsy of animals testing positive followed PNCEBT standards in collaboration with the Agricultural and Livestock Defense Agency of the State of Paraíba.

Samples were collected from any organ with lesions suggestive of tuberculosis. In addition, samples of parotid, sublingual, retropharyngeal, mediastinal and mesenteric lymph nodes were collected in cases without lesions. A portion of each sample was frozen for further use in mycobacteria isolation and identification, while the other portion was fixed in $10 \%$ formaldehyde for histopathological examination. The $10 \%$ formalin-fixed samples were routinely cleaved and processed for the preparation of histopathological slides stained with Hematoxylin and Eosin (HE), according to the technique by BEHMER et al. (1976).

Tissue fragments were decontaminated by the heterotrophic plate count (HPC) method (AMBROSIO et al., 2008) for mycobacteria isolation, with duplicate inoculation in Stonebrink-Leslie and Lowenstein-Jensen media and incubation at $37^{\circ} \mathrm{C}$ for 90 days. Colonies suggestive of mycobacteria were collected for Ziehl-Neelsen staining and DNA extraction using thermolysis (MAZARS et al., 2001). Only samples identified as acid-alcohol resistant bacillus (AARB) by Ziehl-Neelsen staining were submitted to molecular identification.

Mycobacteria identification and differentiation between $M$. tuberculosis complex, $M$. avium complex, M. intracellulare complex and Mycobacterium spp. were performed using the TB Multiplex-polymerase chain reaction (PCR) (WILTON; COUSINS, 1992). To do so, the primers used were: MYCGEN-F (G1) (5'-AGAGTTTGATCCTGGCTCAG-3') and MYCGEN-R (G2) (5'-TGCACACAGGCCACAAGGGA-3') - related to genus; TB-1F (5'-GAACAATCCGGAGTTGACAA-3') and TB-1R (5'-AGCACGCTGTCAATCATGTA-3') related to the $M$. tuberculosis complex; MYCAV-R ( 5' - ACCAGAAGACATGCGTCTTG-3') related to the $M$. avium complex; and MYCINT-F (5'-CCTTTAGGCGCATGTCTTTA-3') - related to the M. intracellulare complex. AN5 strains for M. bovis and $\mathrm{H} 37 \mathrm{Rv}$ for $M$. tuberculosis were used as positive controls. Reactions with $50 \mu \mathrm{L}$ were performed, containing the dNTP reaction buffer (1.25 mM each), 20 pmol of each oligonucleotide, $50 \mathrm{mM}$ $\mathrm{KCl}, 10 \mathrm{mM}$ Tris- $\mathrm{HCl}(\mathrm{pH} 8.3), 1.5 \mathrm{mM} \mathrm{MgCl}, 10 \mathrm{pmol} / \mu \mathrm{L}$ of primers, 1.25 units of Taq polymerase $(1.0 \mu \mathrm{L})$ and $5 \mu \mathrm{L}$ of the DNA under study. The amplification cycles used were: initial denaturation at $94^{\circ} \mathrm{C}$ for 10 minutes, $61^{\circ} \mathrm{C}$ for 2 minutes, 
and $72^{\circ} \mathrm{C}$ for 3 minutes; 33 cycles of $94^{\circ} \mathrm{C}$ for 30 seconds, $61^{\circ} \mathrm{C}$ for 2 minutes, and $72^{\circ} \mathrm{C}$ for 3 minutes; 1 cycle of $94^{\circ} \mathrm{C}$ for 30 seconds, $61^{\circ} \mathrm{C}$ for 2 minutes, and $72^{\circ} \mathrm{C}$ for $10 \mathrm{~min}$ utes. Samples with amplification of 1030 bp were identified as belonging to the genus Mycobacterium, and samples with fragments of $372 \mathrm{bp}$ were considered part of the M. tuberculosis complex (WILTON; COUSINS, 1992).

All DNA samples with consistent amplification for $M$. tuberculosis using TB Multiplex-PCR were amplified with primers RD4 (RD4-1 5'-ATGTGCGAGCTGAGCGATG-3'; RD4-2 5'-TGTACTATGCTGACCCATGCG-3'; and RD4-3 5'-AAAGGAGCACCATCGTCCAC-3') for the identification of M. bovis (WARREN et al., 2006). Reactions with $25 \mu \mathrm{L}$ were performed, containing the dNTP reaction buffer (1.25 mM each), 20 pmol of each oligonucleotide, $50 \mathrm{mM}$ $\mathrm{KCl}, 10 \mathrm{mM}$ Tris- $\mathrm{HCl}(\mathrm{pH} 8.3), 1.5 \mathrm{mM} \mathrm{MgCl}$, primers, 1.25 units of Taq polymerase, and $5 \mu \mathrm{L}$ of the genomic DNA studied. AN5 strain for M. bovis and H37Rv for M. tuberculosis were used as positive controls. The PCR cycles used were: initial denaturation at $95^{\circ} \mathrm{C}$ for 15 minutes, 45 cycles of $94^{\circ} \mathrm{C}$ for 1 minute, $62^{\circ} \mathrm{C}$ for 1 minute, and $72^{\circ} \mathrm{C}$ for 1 minute, and 1 cycle of $72^{\circ} \mathrm{C}$ for 10 minutes. Samples with amplification of 268bp were identified as M. bovis, and $172 \mathrm{bp}$ as other mycobacteria of the M. tuberculosis complex.

\section{RESULTS AND DISCUSSION}

In this study, among 32 bovines, only two (6.3\%) presented submandibular edema with clinical signs suggestive of tuberculosis. M. bovis infection in bovines progresses slowly and clinical signs are uncommon. In early stages, depending on the location of lesions, the animals may present progressive cachexia, superficial and/or deep lymph node hyperplasia, dyspnea, cough, mastitis and infertility, among other symptoms
(HEINEMANN et al., 2008). Therefore, effective ante-mortem surveillance for bovine tuberculosis should be based mainly on the detection of infected animals at early stages using sensitive immunodiagnostic tests (RUA-DOMENECH et al., 2006). Furthermore, at necropsy, 21 (65.6\%) animals presented lesions suggestive of tuberculosis. In fact, the recognition of macroscopic lesions associated with tuberculosis, especially during routine sanitary inspections at slaughterhouses, is an important tool for infection diagnosis, contributing to the identification of foci in herds (CAZOLA et al., 2015). In addition, this is one of PNCEBT's strategies of action in collaboration with the official sanitary inspection service, which is fundamental for warranting the supply of products posing low-risk to public health and, consequently, consumer protection (BIFFA et al., 2010; CAZOLA et al., 2015). In other countries such as the USA, Australia and Spain, where inspection services in slaughterhouses and programs for the eradication of tuberculosis are satisfactory, the prevalence of the disease was reduced (KANTOR; RITACCO, 2006; RUA-DOMENECH, 2006).

In this study, nodular granulomatous lesions with focal and disseminated calcified and caseous appearance, varying in size and shape (Figs. 1A and 1B), were macroscopically observed. Moreover, a granulomatous inflammatory process was microscopically observed at different stages of evolution, with an extensive granuloma characterized by central area coagulative necrosis, homogeneous eosinophilic material, fragmented nuclei, nuclear remnants and foci of mineralization, surrounded by inflammatory infiltrates predominantly of macrophages and epithelioid cells, encapsulated by abundant fibrous connective tissue associated with several layers of mononuclear cells (Figs. 2A and 2B).

Similar findings were observed by MENDES et al. (2013), who used bovine animals slaughtered at a Federal Inspection Service in the State of Santa Catarina and found microscopic lesions characterized by central caseification necrosis composed of homogeneous eosinophilic material, cell debris and a variable
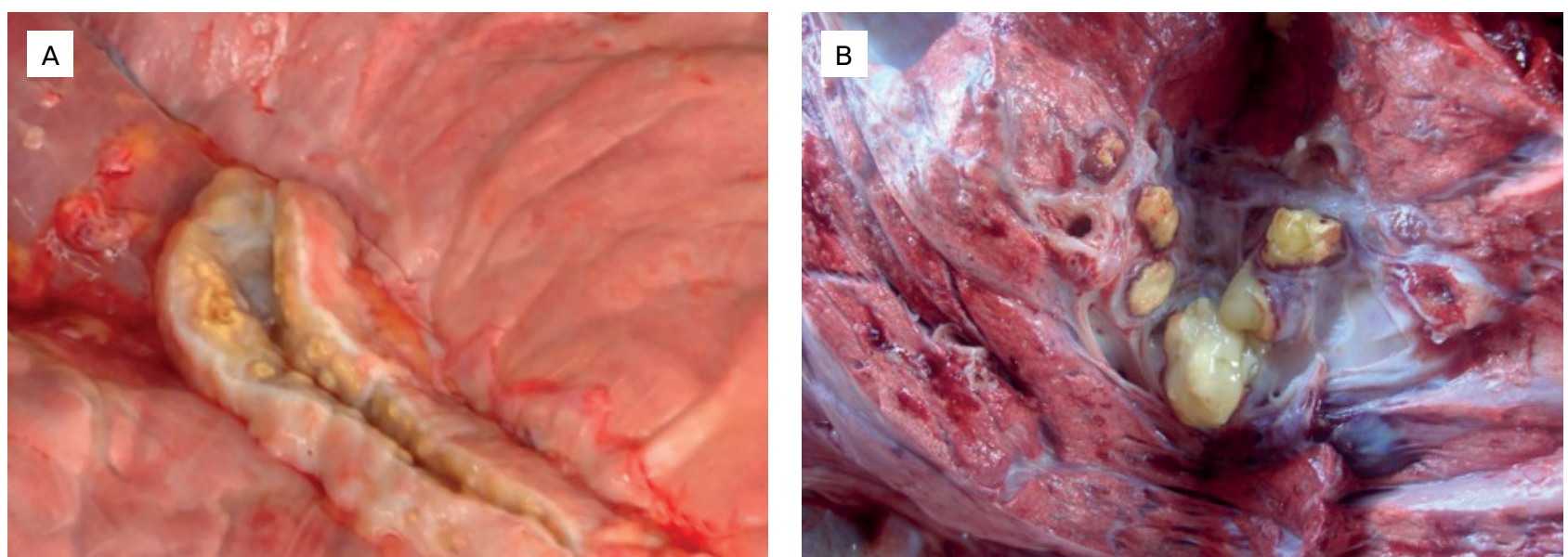

Figure 1. (A) Mediastinal lymph node showing caseous nodules. (B) Lung with disseminated caseous nodules of varying size and shape. 
amount of mineralization surrounded by large amounts of macrophages and multinucleated Langhans giant cells, connective tissue and neutrophils in some cases. Similarly, FRANÇA et al. (2013) assessed cattle slaughtered in Bahia and described tuberculous lesions with a slightly different structure of adjacent tissue and nodules with amorphous mass filled with encapsulated caseous material, sometimes with coalescing multifocal areas.

A total of 121 samples with macroscopic lesions suggestive of tuberculosis were collected and distributed as follows: 80 (66.1\%) lymph node samples (41 mediastinal, 9 mesenteric, 7 submandibular, 13 tracheobronchial, 8 retropharyngeal, and 2 mammary) 37 (30.6\%) from the lung, one (0.83\%) from the liver and three $(2.5 \%)$ from miliary lesion in muscle. As to body region, $94(77.7 \%)$ lesions were found in the thoracic cavity, 15 (12.4\%) in the head and 12 (9.9\%) in the abdominal cavity. PROAÑO-PÉREZ et al. (2011) evaluated the distribution of lesions in organs from cattle slaughtered in Ecuador as indicator of the possible transmission route, and verified macroscopic lesions in mediastinal lymph nodes (51.3\%), tracheobronchial lymph nodes $(23.7 \%)$, retropharyngeal lymph nodes $(9.2 \%)$, liver $(11.8 \%)$ and other areas (3.9\%). In Ethiopia, $84 \%$ of the visible lesions were found in the lungs and thoracic lymph nodes (TEKLUL et al., 2004). Moreover, BIFFA et al. (2012) evaluated 337 carcasses with lesions suggestive of tuberculosis and observed that they were more frequent in the lungs and respiratory lymph nodes (50.9\%), followed by mesenteric and intestinal lymph nodes (16.5\%). In Brazil, ALZAMORA FILHO et al. (2014) reported lesions suggestive of tuberculosis in the pulmonary parenchyma, head and mediastinal lymph nodes in $75 \%(135 / 180)$ of findings in sanitary inspection. CAZOLA et al. (2015) reported that, among 13 bovines with positive reaction to the tuberculin test, seven (53.8\%) had at least one lesion suggestive of tuberculosis in retropharyngeal, parotid and pulmonary lymph nodes or in the lung, and six (46.2\%) had no lesions suggestive of the disease. These results corroborate the findings of the present study and reinforce the role of the respiratory route in the transmission of mycobacteria. The lower frequency of lesions in the abdominal cavity can be attributed to the fact that, in adult cattle, the oral route is secondary to respiratory, which justifies the greater frequency of lesions in thoracic cavity lymph nodes (PALMER; WALTERS, 2006; TAYLOR et al., 2007).

For the isolation and identification of mycobacteria, 55 samples were used, of which 31 (56.4\%) presented lesions suggestive of tuberculosis and 24 (43.6\%) had no macroscopic lesions. In total, mycobacteria were isolated in 31 (56.4\%) samples. In 13 (41.9\%) samples, M. bovis was identified, while in the other 18 (58.1\%) samples, Mycobacterium spp. was present (Table 1). From an epidemiological point of view, it is very important to identify the species of mycobacteria and the possible source of infection for humans, since the disease caused by $M$. tuberculosis and M. bovis in humans is indistinguishable by clinical, radiological and pathological methods (ROCHA et al., 2011; WEDLOCK et al., 2002). However, information about the prevalence of $M$. bovis infection in humans is scarce, since in most cases the isolation and identification of the agent is not carried out, which makes it impossible to identify the source of infection. On the other hand, it is estimated that about $3.1 \%$ of cases of human tuberculosis around the world are caused by M. bovis (EL SAYED et al., 2015).
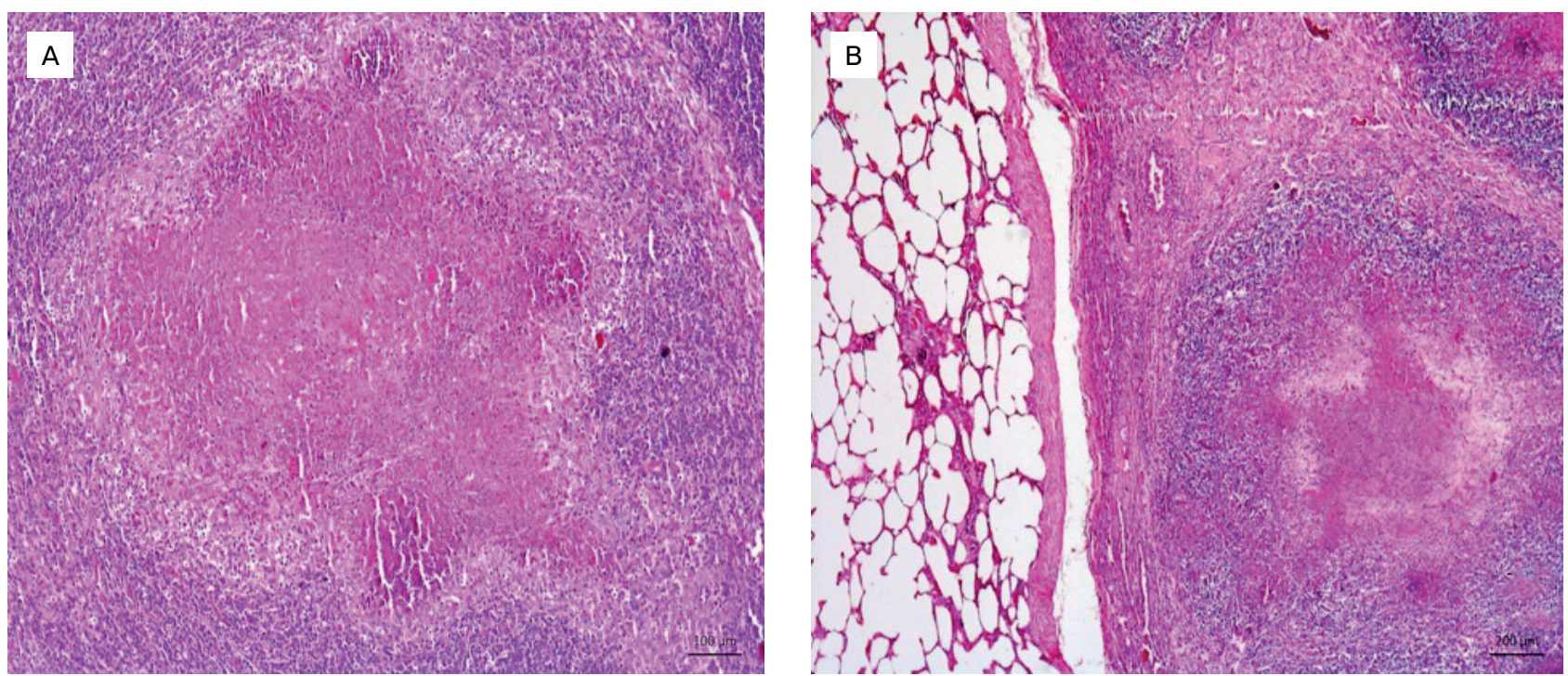

Figure 2. (A) Mediastinal lymph node showing central area of necrosis, with homogeneous eosinophilic material, fragmented nuclei, nuclear remnants and foci of mineralization. Adjacent to the area of necrosis, there is granulomatous inflammation consisting of macrophages, epithelioid cells and numerous lymphocytes. There is also a discrete proliferation of fibrous connective tissue. Obj. 10X, HE. Bar scale $=100 \mu \mathrm{m}$; (B) Lung with extensive granuloma characterized by central area of coagulative necrosis, surrounded by inflammatory infiltrates predominantly of macrophages and epithelioid cells encapsulated by abundant fibrous connective tissue associated with several layers of mononuclear cells. Obj. 5X, HE. Bar scale $=200 \mu \mathrm{m}$. 
Thus, the combination of mycobacterial isolation from bovine tissues and molecular identification contributes to a better understanding of the epidemiology of $M$. bovis infections, thus increasing the efficiency of disease control programs (CAZOLA et al., 2015).

The identification of Mycobacterium spp. in 18 (58.1\%) samples with positive isolation, most isolates coming from mediastinal $(6 ; 33.3 \%)$ and mesenteric $(4 ; 22.2 \%)$ lymph nodes, was an important part of this study. These isolates are likely to be nontuberculous mycobacteria (NTMs), which are present in the environment and can be transmitted to both animals and humans through inhalation or ingestion, resulting in permanent or temporary colonization of the respiratory and digestive tracts (PRIMM et al., 2004). Mycobacterium gordonae, $M$. fortuitum, $M$. intracellulare, $M$. flavescens, $M$. duvalii, $M$. haemophilum, M. immunogenum, $M$. lentiflavum, $M$. mucogenicum, $M$. novocastrense, $M$. parafortuitum, $M$. smegmatis, $M$. terrae, and $M$. vaccae are among the NTM species that have already been identified in animals with positive tuberculin test in Brazil (FRANCO et al., 2013). In another study also conducted with animals testing positive for tuberculin, the following species were identified through

Table 1. Results of culture analysis and identification of samples using TB Multiplex-PCR for amplification of $M$. tuberculosis complex and RD-4 primers for identification of M. bovis in the state of Paraíba, from March to November 2014.

\begin{tabular}{|c|c|c|c|c|c|}
\hline Bovine & Municipality & Propriety & Tissue & Culture & Molecular identification \\
\hline \multirow{2}{*}{03} & \multirow{2}{*}{ Cacimba de Areia } & \multirow{2}{*}{$A$} & Mesenteric lymph node & \multirow{2}{*}{ Positive } & Mycobacterium spp. \\
\hline & & & Mediastinal lymph node & & M. bovis \\
\hline 04 & Cacimba de Areia & A & Mesenteric lymph node & Positive & Mycobacterium spp. \\
\hline 06 & Cacimba de Areia & B & Submandibular lymph node & Positive & Mycobacterium spp. \\
\hline 07 & São Mamede & C & Lung & Positive & M. bovis \\
\hline 08 & São Mamede & $\mathrm{C}$ & Mesenteric lymph node & Positive & Mycobacterium spp. \\
\hline 09 & São Mamede & $\mathrm{C}$ & Lung & Positive & Mycobacterium spp. \\
\hline 11 & Patos & $\mathrm{D}$ & Neck lesion & Positive & Mycobacterium spp. \\
\hline 12 & Patos & $\mathrm{D}$ & Lung & Positive & M. bovis \\
\hline \multirow{2}{*}{13} & \multirow{2}{*}{ Patos } & \multirow{2}{*}{ D } & Submandibular lymph node & \multirow{2}{*}{ Positive } & Mycobacterium spp. \\
\hline & & & Mediastinal lymph node & & Mycobacterium spp. \\
\hline 14 & Patos & $\mathrm{D}$ & Neck lesion & Positive & Mycobacterium spp. \\
\hline \multirow{2}{*}{15} & \multirow{2}{*}{ Patos } & \multirow{2}{*}{ D } & Tracheobronchial lymph node & \multirow{2}{*}{ Positive } & M. bovis \\
\hline & & & Mediastinal lymph node & & Mycobacterium spp. \\
\hline 16 & Patos & $\mathrm{D}$ & Mediastinal lymph node & Positive & Mycobacterium spp. \\
\hline 17 & Patos & $\mathrm{D}$ & Lung & Positive & M. bovis \\
\hline \multirow{2}{*}{18} & \multirow{2}{*}{ Patos } & \multirow{2}{*}{$\mathrm{E}$} & Lung & \multirow{2}{*}{ Positive } & M. bovis \\
\hline & & & Retropharyngeal lymph node & & M. bovis \\
\hline 19 & Patos & $\mathrm{E}$ & Mediastinal lymph node & Positive & Mycobacterium spp. \\
\hline 20 & Patos & $\mathrm{E}$ & Tracheobronchial lymph node & Positive & M. bovis \\
\hline 21 & Patos & $\mathrm{E}$ & Lung & Positive & Mycobacterium spp. \\
\hline 23 & Patos & $\mathrm{F}$ & Mammary lymph node & Positive & Mycobacterium spp. \\
\hline 24 & Patos & G & Miliary lesion (Thorax) & Positive & M. bovis \\
\hline \multirow{2}{*}{25} & \multirow{2}{*}{ Patos } & \multirow{2}{*}{ G } & Mediastinal lymph node & \multirow{2}{*}{ Positive } & M. bovis \\
\hline & & & Tracheobronchial lymph node & & Mycobacterium spp. \\
\hline 26 & Patos & G & Lung & Positive & M. bovis \\
\hline 28 & Patos & $\mathrm{H}$ & Lung & Positive & M. bovis \\
\hline 29 & Patos & $\mathrm{H}$ & Mediastinal lymph node & Positive & Mycobacterium spp. \\
\hline 31 & Patos & $\mathrm{H}$ & Mesenteric lymph node & Positive & Mycobacterium spp. \\
\hline \multirow{2}{*}{32} & \multirow{2}{*}{ Patos } & \multirow{2}{*}{$\mathrm{H}$} & Mediastinal lymph node & \multirow{2}{*}{ Positive } & Mycobacterium spp. \\
\hline & & & Mesenteric lymph node & & M. bovis \\
\hline
\end{tabular}


sequencing: $M$. engbaekii, $M$. arupense, $M$. nonchromogenicum and $M$. heraklionense (BOLAÑOS et al., 2018).

Currently, the increase in number of cases of individuals infected with human immunodeficiency virus (HIV) leads to the rise in number of cases of emerging and reemerging diseases, especially those caused by opportunistic etiological agents such as Mycobacterium spp. In this context, direct contact with sources of infection and consumption of contaminated meat, milk and dairy products pose a serious risk of agent transmission to individuals with HIV and other immunosuppressive conditions.

\section{CONCLUSIONS}

Conclusion is that the isolation and identification of $M$. bovis and Mycobacterium spp. in bovines with positive reaction to tuberculin test in the state of Paraíba, northeast Brazil, suggests that humans are exposed to the risk of infection. This result reinforces the need for intensification and optimization of prevention and control measures outlined in the PNCEBT, such as the incentive to certification of controlled and free rural properties for tuberculosis and measures of measures of animal movement and fairs control. Moreover, particular attention should be given to sanitary inspection of slaughterhouses to identify outbreaks of the disease, as well as to isolate and classify mycobacteria in other states of the northeast region of Brazil.

\section{ACKNOWLEDGMENTS}

To the National Council for Scientific and Technological Development (CNPq) for the financial support (number 302222/2016-2), and to the Agricultural and Livestock Defense Agency of the State of Paraíba.

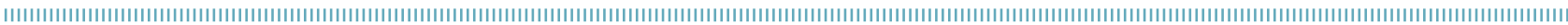
REFERENCES

ALZAMORA FILHO, F.; VASCONCELOS, S. E. G.; GOMES, H. M.; CAVALCANTE, M. P.; SUFFY, P. N.; COSTA, J. N. Múltiplas estirpes de isolados de Mycobacterium bovis identificados por tipagem molecular em bovinos abatidos em matadouros-frigoríficos. Pesquisa Veterinária Brasileira, Seropédica, v.34, n.2. p.103-108, 2014.

AMBROSIO, S. R.; OLIVEIRA, E. M. D.; RODRIGUEZ, C. A. R.; FERREIRA NETO, J. S.; AMAKU, M. Comparison of three decontamination methods for Mycobacterium bovis isolation. Brazilian Journal of Microbiology, São Paulo, v.39, n.2, p.241-244, 2008.

BEHMER, O. A.; TOLOSA, E. M. C.; FREITAS NETO, A. G. Manual de técnicas para histologia normal e patológica. Ed. Art. São Paulo: EDUSP, 1976. 259 p.

BIFFA, D.; BOGALE, A.; GODFROID, J.; SKJERVE, E. Factors associated with severity of bovine tuberculosis in Ethiopian cattle. Tropical Animal Health and Production, Edinburgh, v.44, n.5, p.991-998, 2012

BIFFA, D.; BOGALE, A.; SKJERVE, E. Diagnostic efficiency of abattoir meat inspection service in Ethiopia to detect carcasses infected with Mycobacterium bovis: Implications for public health. BMC Public Health, London, v.10, n.462, p.1-12, 2010.

BOLAÑOS, C.A.D.; FRANCO, M.M.J.; SOUZA FILHO, A.F.; IKUTA, C.Y.; BURBANO-ROSERO, E.M.; FERREIRA NETO, J.S.; HEINEMANN, M.B.; MOTTA, R.G.; PAULA, C.L.; MORAIS, A.B.C.; GUERRA, S.T.; ALVES, A.C.; LISTONI, F.J.P.; RIBEIRO, M.G. Nontuberculous mycobacteria in milk from positive cows in the intradermal comparative cervical tuberculin test: implications for human tuberculosis infections. Revista do Instituto de Medicina Tropical, São Paulo, v.60, p.1-8, 2018.
BRASIL. MINISTÉRIO DA AGRICULTURA, PECUÁRIA E ABASTECIMENTO - MAPA. Programa Nacional de controle e erradicação da brucelose e da tuberculose animal (PNCEBT). Brasília: MAPA, 2006. 188 p. (Manual técnico).

. MINISTÉRIO DA SAÚDE - MS. Secretária de Vigilância em Saúde. Departamento de Vigilância Epidemiológica. Sistema de Informação de Agravos de Notificação - Sinan. Available from: < http:// portalsaude.saude.gov.br/images/pdf/2015/setembro/24/ Casos-novos-tuberculose-1990-2014-base-jun-2015.pdf >. Accessed on: Jan. 102016.

CAZOLA, D.O.; JORGE, K.S.G.; ZUMÁRRAGA, M.J.; SOUZA-FILHO, A.F.; FLÁBIO, R.; ARAÚJO, F.R.; ANA LUIZA, A.R.; OSÓRIO, A.R.O. Identificação e genotipagem de Mycobacterium bovis em bovinos positivos no teste intradérmico para tuberculose em Mato Grosso do Sul. Pesquisa Veterinária Brasileira, Seropédica, v. 35, n. 2, p.141-147, 2015

EL-SAYED, A.; EL-SHANNAT, S.; KAMEL, M.; CASTAÑEDA-VAZQUEZ, M.A.; CASTAÑEDA-VAZQUEZ, H. Molecular epidemiology of Mycobacterium bovis in humans and cattle. Zoonoses and Public Health, Indianapolis, v.63, n.4, p.251-264, 2015.

FRANÇA, L.R.; CRUZ, J.F.; NEVES, V.B.F.; CERQUEIRA, R.B. Prevalência e histopatologia de lesões sugestivas de tuberculose em carcaça de bovinos abatidos no Sudoeste da Bahia. Revista Brasileira Saúde e Produção Animal, Salvador, v. 14, n.4, p.721-733, 2013.

FRANCO, M.M.J.; PAES, A.C.; RIBEIRO, M.G.; PANTOJA, J.C.F.; SANTOS, A.C.B.; MIYATA, M.; LEITE, C.Q.F.; MOTTA, R.G.; LISTONI, F.J.P. Occurrence of mycobacteria in bovine milk samples from both individual and collective bulk tanks at farms and informal markets in the southeast region of São Paulo, Brazil. BMC Veterinary Research, London, v.9, n.85, p.1-8, 2013. 
HEINEMANN, M.B.; MOTA, P.M.P.C.; LOBATO, F.C.F.; LEITE, R.C.; LAGE, A.P. Tuberculose bovina: uma introdução à etiologia, cadeia epidemiológica, patogenia e sinais clínicos. Cadernos Técnicos de Veterinária e Zootecnia, Belo Horizonte, v.59, p. 1-12, 2008.

KANTOR. I.N.; RITACCO, V. An update on bovine tuberculosis programmes in Latin American and Caribbean countries. Veterinary Microbiology, Geneva, v.112, n. 2-4, p.111-118, 2006.

MAZARS, E.; LESJEAN, S.; BANULS, A.; GILBERT, M.; VICENT, V.; GICQUEL, B.; TIBAYRENC, M.; LOCHT, C.; SUPPLY, P. High-resolution minisatellite-based typing as a portable approach to global analysis of Mycobacterium tuberculosis molecular epidemiology. Proceedings of the National Academy of Sciences of the United States of America, Washington, v.98, n.4, p. 1901-1906, 2001.

MENDES, R.E.; SCHNEIDER, A.F.; WERLICH, D.E.; LUCCA, N.J.; LORENZETT, M.P.; PILATI, C. Estudo anatomopatológico em tecidos condenados pelo serviço de inspeção federal (SIF) por suspeita de tuberculose. Ciência Animal Brasileira, Goiânia, v.14, n.4, p.448-453, 2013.

OCEPEK, M.; PATE, M.; ZOLNIR-DOVC, M.; POLJAK, M. Transmission of Mycobacterium tuberculosis from human to cattle. Journal of Clinical Microbiology, Washington, v.43, n.7, p.3555-3557, 2005.

PALMER, M.V.; WATERS, W.R. Advances in bovine tuberculosis diagnosis and pathogenesis: what policy makers need to know. Veterinary Microbiology, Geneva, v. 1 12, n.2-4, p.181-190, 2006.

PRIMM, T.P.; LUCERO, C.A.; FALKINHAM, J.O. Health Impacts of Environmental Mycobacteria. Clinical Microbiology Reviews, Washington, v.17, n.1, p.98-106, 2004.

PROAÑO-PÉREZ, F.; BENITEZ-ORTIZ, W.; DESMECHT, D.; CORAL, M.; ORTIZ, J.; RON, L.; PORTAELS, F.; RIGOUTS, L.; LINDEN, A. Post-mortem examination and laboratory-based analysis for the diagnosis of bovine tuberculosis among dairy cattle in Ecuador. Preventive Veterinary Medicine, Amsterdam, v.101, n. 1-2, p.65-72, 2011.

ROCHA, A.; ELIAS, A.R.; SOBRAL, L.F.; SOARES, D.F.; SANTOS, A.C.; MARSICO, A.G.; HACKER, M.A.; CALDAS, P.C.; PARENTE, L.C.; SILVA, M.R.; FONSECA, L.; SUFFYS, P.; BOÉCHAT, N. Genotyping did not evidence any contribution of Mycobacterium bovis to human tuberculosis in Brazil. Tuberculosis, Edinburgh, v.91, n.1, p. 14-21, 2011.

RODRIGUEZ, C.A.R.; ZUMÁRRAGA, M.J.; OLIVEIRA, E.M.D.; CATALDI, A.A.; ROMANO, M. I.; OTTO, H.H.; BONAFÉ, V.L.;
FERREIRA NETO, J.S. Caracterização molecular de isolados de Mycobacterium bovis do Estado de São Paulo Brasil, utilizando a técnica de spoligotyping. Arquivos do Instituto Biológico, São Paulo, v.71, n.3, p.277-282, 2004.

RUA-DOMENECH, R. Human Mycobacterium bovis infection in the United Kingdom: Incidence, risks, control measures and review of the zoonotic aspects of bovine tuberculosis. Tuberculosis, Edinburgh, v. 86, n. 2, p. 77-109, 2006.

RUA-DOMENECH, R.; GOODCHILD, A.T.; VORDERMEIER, H.M.; HEWINSON, R.G.; CHRISTIANSEN, K.H.; CLIFTON-HADLEY, R.S. Ante mortem diagnosis of tuberculosis in cattle: a review of the tuberculin tests, gamma-interferon assay and other ancillary diagnostic techniques. Research in Veterinay Science, London, v.81, n.2, p.190-210, 2006.

TAYLOR, G.M.; WORTH, D.R.; PALMER, S.; JAHANS, K.; HEWINSON, $G$. Rapid detection of Mycobacterium bovis DNA in cattle lymph nodes with visible lesions using PCR. Veterinary Research, London, v.3, n.12, p.1-11, 2007.

TEKLU, A.; ASSEGED, B.; YIMER, E.;GEBEYEHU, M.; WOLDESENBET, $Z$. Tuberculous lesions not detected by routine abattoir inspection: the experience of the Hossana municipal abattoir, southern Ethiopia. Revue Scientifique et Technique (International Office of epizootics), Hannover, v.23, n.3, p.957-964, 2004.

WARREN, R.M.; GEY VAN PITTIUS, N.C.; BARNARD, M.; HESSELING, A.; ENGELKE, E.; DE KOCK, M.; GUTIERREZ, M.C.; CHEGE, G.K.; VICTOR, T.C.; HOAL, E.G.; VAN HELDEN, P.D. Differentiation of Mycobacterium tuberculosis complex by PCR amplification of genomic regions of difference. International Journal of Tuberculosis and Lung Disease, Paris, v.10, n.7, p.818-822, 2006.

WEDLOCK, D.N.; SKINNER, M.A.; LISLE, G.W.; BUDDLE, B.M. Review Control of Mycobacterium bovis infections and the risk to human populations. Microbes and Infection, Amsterdam, v.4, n.4, p.471-480, 2002.

WILTON, S.; COUSING, D. Detection and identification of multiple mycobacterial pathogens by DNA amplification in a single tube. Genome Research, Cold Spring Harbor, v.1, n.4, p.269-273, 1992.

ZANINI, M.S.; MOREIRA, E.C.; LOPES, M.T.P.; OLIVEIRA, R.S.; LEÃO, S.C.; FIORAVANTI, R.I.; ROXO, E.; ZUMÁRRAGA, M.; ROMANO, M.I.; CATALDI, A.; SALAS, C.E. Mycobacterium bovis: Polymerase Chain Reaction identification in bovine lymphonode biopsies and genotyping in isolates from Southeast Brazil by Spolygotyping and Restriction Fragment Length Polymorphism. Memórias do Instituto Oswaldo Cruz, Rio de Janeiro, v.96, n.6, p.809-813, 2001. 